\title{
Hoosier Emergency Powers: Restoring CHECKS AND BALANCES
}

\author{
JOSHUA A. CLAYBOURN* \& ABBY V. DEMARE**
}

\section{INTRODUCTION}

Emergencies occur in many forms-terrorist attacks, environmental catastrophes, natural disasters, riots, and pandemics, to name a few. Such emergencies lead, in turn, to far-reaching problems. Long ago and in the recent past, policymakers saw that existing laws might hinder emergency responses and further endanger public health and safety. Like many other states, Indiana addressed this danger by adopting laws specifically granting the executive branch broad flexible powers. ${ }^{1}$

Emergency powers originate in the belief that a centralized, streamlined response wielded by the executive can succeed more quickly and efficiently than a normal legislative process. ${ }^{2}$ But authority vested solely in the executive branch includes many potential abuses of power-particularly when the executive possesses the sole authority to declare an emergency and then respond to it. During the pandemic of coronavirus disease 2019 ("COVID-19" or "coronavirus pandemic"), authorities worldwide and in Indiana enacted travel restrictions, lockdowns, business closures, and mask mandates to slow the disease's spread. ${ }^{3}$ For some of the most consequential government actions in generations, in Indiana one elected official - the governor-made every decision with no formal checks or balances. ${ }^{4}$

* Attorney, Jackson Kelly PLLC; J.D. 2006, Indiana University Robert H. McKinney School of Law; B.S. 2003, Indiana University - Bloomington, Indiana.

** J.D. 2021, Indiana University Robert H. McKinney School of Law; B.A. 2018, Furman University - Greenville, South Carolina.

1. IND. CODE $\S 10-14-3-7$ (a) (2020) ("Because of the existing and increasing possibility of disasters or emergencies of unprecedented size and destructiveness that may result from manmade or natural causes, to ensure that Indiana will be adequately prepared to deal with disasters or emergencies or to prevent or mitigate those disasters where possible, generally to provide for the common defense, to protect the public peace, health, and safety, and to preserve the lives and property of the people of the state, it is found and declared to be necessary: (1) to provide for emergency management under the department of homeland security; (2) to create local emergency management departments and to authorize and direct disaster and emergency management functions in the political subdivisions of the state; (3) to confer upon the governor and upon the executive heads or governing bodies of the political subdivisions of the state the emergency powers provided in this chapter....").

2. See Gregory Sunshine, The Case for Streamlining Emergency Declaration Authorities and Adapting Legal Requirements to Ever-Changing Public Health Threats, 67 EMORY L.J. 397 (2018).

3. Lockdowns Compared: Tracking Governments' Coronavirus Responses, FIn. TIMES (Aug. 11, 2021), https://ig.ft.com/coronavirus-lockdowns/ [https://perma.cc/9HJW-E3GE].

4. Ethan May \& Shari Rudavsky, Gov. Holcomb Announces New Coronavirus Phase: It's Stage 4.5, IndiANAPOLIS STAR (July 15, 2020), https://www.indystar.com/story/news/health/ 
When public emergencies arise in a functioning democracy, a natural tension develops between the need for prompt, efficient action on the one hand, and the desire to act within the checks and balances prescribed under rule of law on the other hand. Such balancing led Abraham Lincoln to ponder in 1861, "Is there, in all republics, this inherent and fatal weakness? Must a government, of necessity, be too strong for the liberties of its own people, or too weak to maintain its own existence?" Although few American executives abused their powers during the coronavirus pandemic, many executives did resort to a dizzying array of irrational and contradictory rules. ${ }^{6}$ And history teaches us that some executives will inevitably abuse their authority after opening Pandora's box of emergency powers. ${ }^{7}$ This conundrum is what motivated America's Founders to divide power among several governing institutions, even during emergencies ${ }^{8}$; yet this division of power continues to blur. Studying emergency powers necessarily involves studying separation of powers - that unique delineation of authority and responsibility among the independent branches in order to foster a system of checks and balances.

Part I of this Article explores the history of separation of powers - in ancient Rome, during America's founding, and in Indiana - and how emergencies can upset important checks and balances. Part II offers an overview of modern emergency powers. Part III suggests reforms to current Indiana emergency powers. This Article urges revision to Indiana's emergency powers in order to incorporate checks and balances while maintaining a streamlined, flexible legal system for emergency response. Specifically, all emergency declarations should carry a sunset provision requiring legislative approval for renewal or extension; emergency declarations should require approval from designated leaders of both the House of Representatives and the Senate; and the Indiana General Assembly should possess authority to call a special session to address any emergency legislative needs or gubernatorial overreach.

\section{THE NEED FOR SEPARATION OF POWERS: A BRIEF HISTORY}

\section{A. Roman Separation of Powers}

During Rome's monarchical period, seven kings ruled with the advice of a

2020/07/01/coronavirus-indiana-new-stage-begin-Saturday-slow-spread-covidhotspots/5358005002/ [https://perma.cc/NF7L-WWEU].

5. President Abraham Lincoln, Message to Congress in Special Session, 4 July 1861, in Collected Works of Abraham Lincoln 4:432-37 (Roy P. Basler ed., 1953).

6. Nina Feldman, Confusion Reigns Nationwide Amid Conflicting Coronavirus Rules, NPR (July 26, 2020), https://www.npr.org/2020/07/26/895480870/confusion-reigns-nationwide-amidconflicting-coronavirus-rules [https://perma.cc/35SP-S4MA].

7. See generally The Use And ABuse of Power (Annette Y. Lee-Chai and John A. Bargh eds., 2001).

8. Cong. Research Serv., The Constitution of the United States of America: ANALYSis AND InTERPRETATION, S. Doc. No. 112-9, at 65-67 (2017). 
Curiate Assembly and a Senate. ${ }^{9}$ At first, citizens from land-owning families elected the king, who served for life..$^{10}$ He served as chief executive, head of the military, judicial authority, and chief priest. ${ }^{11}$ Through this period and in the absence of laws, the king held absolute power. ${ }^{12}$ The first king, Romulus, founded the Senate by appointing 300 of the noblest (wealthiest) family men, with 100 coming from each of the three ancient Roman tribes-Latins, Sabines, and Etruscans. ${ }^{13}$ The Senate and Assembly lacked the right to meet and discuss Rome's business - only the king could call them together, and they discussed only matters on the king's agenda. ${ }^{14}$ Though the Assembly might pass laws the king proposed, the Senate merely advised. ${ }^{15}$

The monarchy ended when the Senate overthrew the last king, Lucius Tarquinius Superbus, who had risen to power by killing, with his wife's help, the previous king, his father-in-law, beginning the Roman Republic with a strong Senate. ${ }^{16}$ After the exile of the last king, two of his relatives, noblemen from the Senate, became Rome's first two consuls - executives chosen from and by the Senate. ${ }^{17}$ With Senate approval, the consuls also appointed a chief priest to assume responsibility for all religious duties formerly performed by the king. ${ }^{18}$

Through most of the Republic and well into the Empire, Rome continued to rely on the Assembly, the Senate, and two consuls for governance. ${ }^{19}$ The nature of the Assembly changed when plebeians gained power and elected their own

9. George Mousourakis, A Legal History of Rome 7, 16 (2007).

10. Id. at 3,6 .

11. Id.

12. Id. at 7. As chief executive, he appointed officials - e.g., the tribune who convened the Curiate Assembly (membership based on Rome's thirty curiae, a mainly ethnic division of families), the warden of the city of Rome, and the patricians who constituted the Senate. Moreover, as chief priest and augur, the king conducted all religious ceremonies. The one limitation on the king's power involved foreign war: he needed approval from both the Senate and the Curiate Assembly to declare war against a foreign nation.

13. Id. at 4. From the thirty curiae (ten allotted to each tribe), the king appointed at least one Senator - and only one king could appoint Senators.

14. Id. at 10 .

15. Id. at 59. When a king died, the Senate appointed an interrex, a Senator who served for five days to find an appropriate nominee to become the next Roman king. If the interrex proved unsuccessful, the Senate appointed another to succeed him in seeking a nominee. Eventually, the Curiate Assembly voted on the next king, though the Senate held power to propose a candidate.

16. Id. at 8. Tarquinius' fall and exile occurred in part because his son, Sextus Arquinius, raped Lucretia, a chaste noblewoman, wife and daughter to powerful Roman nobles. As a consequence, the Senators, led by Lucius Junius Brutus, deposed Tarquinius and his family in 509 B.C.

17. Id. at 10-11. Because King Tarquinius had ousted or executed a number of Senators during his 25-year reign, the first consuls immediately replenished the Senate with appointments, returning the total to 300 .

18. Id. at 6-7.

19. See id. at 146. 
Assembly led by tribunes. ${ }^{20}$ But the Senate, which eventually grew to 900 members, continued as a patrician body directing the consuls, the censor, the magistrates, and other officials. ${ }^{21}$ The Senate controlled the civil government in Rome. $^{22}$

During the first two centuries of the Republic, the Senate appointed dictators for terms of six months, principally during military emergencies when Rome needed a strong magistracy to address extraordinary situations. ${ }^{23}$ In addition to fighting wars, dictators allowed the Senate to suppress sedition and control the plebeians' growing powers. ${ }^{24}$ Always a patrician nominated by the consuls and chosen by the Senate, a dictator supported the Senate. ${ }^{25}$ Later, around 300 B.C., the Senate used dictatorship mainly for domestic emergencies (the six-month limit made it impractical to use for foreign wars). ${ }^{26}$

Julius Caesar's demand that the Senate appoint him dictator for life precipitated a civil war which ended the Roman Republic and allowed the Second Triumvirate (Octavian, Marc Antony, and Lepidus) to arrange for the assassinations and executions of many Senators who wished to maintain the power structure and values of the Roman Republic. ${ }^{27}$ Among them was Marcus Tullius Cicero. ${ }^{28}$ Cicero hoped to roll back Julius Caesar's dictatorship by educating Caesar's likely successor, Octavian, in the virtues of republican government. ${ }^{29}$ Even if Julius Caesar would not surrender his power, Cicero hoped to convince the impressionable young Octavian about the value of old republican ways. $^{30}$

Unfortunately, Cicero failed: the Second Triumvirate ordered his assassination. ${ }^{31}$ Soldiers killed him as he tried to flee Italy; Marc Antony displayed his severed hands and head in Rome for his passionate defense of the Senate and criticism of the consuls. ${ }^{32}$ Bruce Fein calls this episode the Cicero Trap - a delusion that, lacking scrupulous separation of powers, statesmanship or noble character can save a nation..$^{33}$ Once Octavian defeated Mark Antony in

20. Id. at 6-9, 15-17.

21. Id. at 7,10 .

22. Id. at $10-11$.

23. Id. at 12,46 .

24. Id. at 13 .

25. See id.

26. Id. The last dictator (before Julius Caesar) was appointed in 202 B.C. to maintain order during the Second Punic War.

27. Id. at 48 .

28. Id.

29. Id. at 64,83 .

30. See id. at 64 .

31. See R.E. Smith, Cicero the Statesman 236-59 (1966).

32. Id.

33. Bruce Fein, Avoiding the Cicero Trap, Am. Conservative, (Apr. 2, 2018), https://www.theamericanconservative.com/articles/avoiding-the-cicero-trap [https://perma.cc/436B4PUS]. 
civil war, he changed his name to Caesar Augustus and exercised all of Julius Caesar's dictatorial powers - and more. ${ }^{34}$ The Roman Senate became ornamental, and the Roman Republic morphed into the Roman Empire. ${ }^{35}$

Early on, Octavian reduced the Senate to 600 members - through execution, assassination, and expulsion for those of low birth and little property. ${ }^{36}$ Though he chose at first the title princeps, suggesting he was merely the "first citizens" among many equals, he eventually became emperor when the Senate, under duress, offered him the title. ${ }^{37}$ The emperor held office for life, and the annually elected consuls served under him. ${ }^{38}$ Both Octavian and Tiberius as emperors sought to hide their influence on and dominance over the Senate. ${ }^{39}$ Subsequent emperors surrendered even the pretense of shared governance. ${ }^{40}$

In the Empire, the tribunal assembly representing plebeians surrendered all powers to the Senate. In theory, the Senate elected new emperors; though, in fact, the emperor usually chose his successor. ${ }^{41}$ Eventually, the Senate became separated from actual government, their duties assumed by the imperial bureaucracy selected and controlled by the executive. ${ }^{42}$ Unchecked by an impotent Senate, Rome's emperors could not resist the instinct for power and conquests. Whether perceived or real, emergencies allowed Rome's executives to wrest power from the Senate and other representatives of the populace. ${ }^{43}$ The Senate as an institution had vanished by A.D. 630 with Europe in the Dark Ages. ${ }^{44}$

Many complicated factors contributed to Rome's demise, but when emergencies arose throughout its long history, executives inevitably abused their new powers. ${ }^{45}$ After opening Pandora's box during emergencies, they often

34. Id.

35. $I d$.

36. Richard J. A. Talbert, Augustus and the Senate, 31 GreECE \& Rome 55, 55-56 (1984).

37. See Andrew Wallace-Hadrill, Civilis Princeps: Between Citizen and King, 72 J. RomaN STUD. 32-48 (1982).

38. Under Augustus, the Senate quorum was originally set at 400. But lack of authority led to excessive absenteeism so that the quorum was diminished regularly and dropped for some issues. Talbert, supra note 36 , at 57.

39. Id.

40. See Olivier Hekster, Emperors and Councillors: Imperial Representation Between Republic and Empire, in New Perspectives on Power And Political Representation from Ancient History to the Present Day:Repertoires of Representation 11-25 (Harm Kaal and Daniëlle Slootjes eds., 2019).

41. Under Vespasian, the Senate gained powers as officials of the imperial household in Rome and as provincial governors representing the emperor. Id.

42. See Hekster, supra note 40.

43. When the Western Empire fell in 476 B.C., barbarian rulers like Odoacer and Theodoric sought to protect the Roman Senate and rule in conjunction with it, a situation that continued till Theodahad rose against Justinian I and took Senators as hostages.

44. Walter E. Kaegi, Heraclius: Emperor of Byzantium 196 (2003).

45. Luke Kemp, The 'Stomp Reflex': When Governments Abuse Emergency Powers, BBC 
continued using those powers even after the emergency subsided. ${ }^{46}$

\section{B. American Separation of Powers}

Near the formation of the United States, many in the West preferred a system ancient Greek and Roman philosophers called a "mixed regime," combining elements of monarchy, oligarchy, and democracy to provide governments the best features of each while avoiding the worst. ${ }^{47}$ A monarchy, "One," offered ideal efficiency in foreign policy and war, but frequently devolved into tyranny. ${ }^{48}$ Government by the "Few" might have fostered wise, virtuous rule, but might have also led to a corrupt, self-interested oligarchy. ${ }^{49}$ Oligarchies often failed to protect rights. ${ }^{50}$ Government by everyone - a pure democracy of "Many" - might have maximized liberty, but might have also degenerated into mob rule..$^{51}$

A mixed regime combining the powers of One, Few, and Many-blending monarchs, oligarchs, and commoners - allows each segment to balance one another and increase chances of just rule..$^{52}$ Ancient Sparta, the Roman Republic, and the Republic of Venice all used a mixed regime in some fashion. ${ }^{53}$ By the 17th century, many Englishmen viewed England as a mixed regime with the monarch, the House of Lords, and the House of Commons each representing the One, the Few, and the Many. ${ }^{54}$

After the American Revolution, the United States adopted a republican form of government with emphasis on the Many, but the country's founders also wished to avoid concentrating power in any one corruptible institution. ${ }^{55}$ As a result, our Founders separated legislative, executive, and judicial powers. ${ }^{56}$ Popularly elected presidents and governors replaced monarchy as the One, the Senate and the Supreme Court replaced the oligarchic Few, and the popularly

(Apr. 28, 2021), https://www.bbc.com/future/article/20210427-the-stomp-reflex-whengovernments-abuse-emergency-powers [https://perma.cc/4CB6-TSW7].

46. $I d$.

47. See Martin Diamond, The Separation of Powers and the Mixed Regime, 8 Publius, Summer 1978, at 33-43; see also M. J. C. Vile, Constitutionalism and the Separation of Powers (1967); W.B. Gwyn, The Meaning of the Separation of Powers: An Analysis of the Doctrine from Its Origin to the Adoption of the United States Constitution (1965).

48. See generally The Federalist No. 47 (James Madison).

49. See Plato, The Republic, in Plato In Twelve Volumes 8.551 (Paul Shorey trans., Harvard Univ. Press 1969) (explaining that an oligarchy — which embraces the rule of a few-leads to "a city of the rich and a city of the poor, dwelling together, and always plotting against one another").

50. Id.

51. See The Federalist No. 55 (James Madison).

52. See Matthew E. Glassman, Cong. Research Serv., R44334, Separation of POWERS: AN OVERVIEW 3 (2016).

53. See id.

54. Id.

55. Id. at 6 .

56. See The Federalist No. 47 (James Madison). 
elected House of Representatives functioned as the Many. The Founders hoped that separating these powers would not only protect the integrity of each branch of government, but also permit each branch to serve as an effective check on the other two. ${ }^{57}$

Unfortunately, emergencies usually highlight tension between executive and legislative branches. Over the years, policymakers sought to resolve this tension in various ways. ${ }^{58}$ Political scientists dubbed formalists or absolutists posit that the government should wield no power to deal with emergencies beyond those the Constitution specifically provides. ${ }^{59}$ They postulate the Constitution draws sharply defined lines among three distinct branches of government. ${ }^{60}$ Our Founders deliberately rejected a European-style parliamentary system in which legislative and executive powers were joined and, instead, placed most American governing power with the people, i.e., the legislative branch representing "Many." ${ }^{\prime 1}$ At the national level, many significant powers - for taxing, spending, declaring war, and confirming members of a president's Cabinet and justices of the Supreme Court - reside with the legislative branch. ${ }^{62}$ Like virtually every other state, Indiana adopted a nearly identical system separating powers to ensure appropriate checks and balances - even during emergencies. ${ }^{63}$

In Ex parte Milligan, a landmark United States Supreme Court case dealing with a Hoosier tried and sentenced to death for disloyalty during the Civil War, the Court expressed this absolutist view by declaring President Lincoln lacked power to create a military commission because the Constitution works "equally in war and in peace" protecting "all classes of men, at all times, and under all circumstances." ${ }^{\prime 4}$ As the Court noted in Milligan, the Framers, no strangers to emergencies themselves, had ample opportunity to include in the Constitution general emergency powers or martial law, but chose not to do so (apart from the power to call out the militia to suppress insurrections and to suspend the writ of

57. Black's Law Dictionary defines "separation of powers" as "the constitutional doctrine of checks and balances by which the people are protected against tyranny." Separation of Powers, BLACK's LAW Dictionary (7th ed. 1999).

58. For a more complete review of various legal approaches to emergency power throughout history, see Jules Lobel, Emergency Power and the Decline of Liberalism, 98 YALE L.J. 1385 (1989).

59. See generally Aziz Z. Huq \& Jon D. Michaels, The Cycles of Separation-of-Powers Jurisprudence, 126 YALE L.J. 346 (2016).

60. See Gary Lawson, Territorial Governments and the Limits of Formalism, 78 CALIF. L. REV. 853, 859-60 (1990) (explaining the theory of formalism).

61. See Gordan S. Wood, Power ANd Liberty: Constitutionalism in the AMERican REVOLuTiOn (2021).

62. See U.S. Const. art. I, $\S 8$.

63. See InD. Const. arts. 3-4.

64. Ex parte Milligan, 71 U.S. 2, 120-21 (1866). Indiana citizen Lambdin P. Milligan was tried and sentenced by a military commission established by President Lincoln. Issued after the Civil War ended, this decision unanimously held that President Lincoln acted unconstitutionally. The decision helped establish limits on presidential powers during war. 
habeas corpus $).{ }^{65}$

Traditionally, states have interpreted a governor's emergency powers in agreement with the U.S. Supreme Court's view of a president's emergency powers. ${ }^{66}$ Although this view favoring the legislature's primacy dominated most of early American and Indiana history, over time the executive became like a centrifuge, sucking power from the legislature and making law through regulation and executive order. ${ }^{67}$ Federal and state legislatures relinquished their constitutional responsibilities and their roles as a check on the executive.

In a second view, often called a "functionalist" or "relativist" view, constitutions should remain flexible and provide the executive branch with wide powers to address crises. ${ }^{68}$ This view rejects the idea that the Constitution provides "a complete division of authority between the three branches," stressing that the separation of powers provides "the integration of dispersed powers into a workable Government." ${ }^{.70}$ In the shadow of World War II, President Franklin Roosevelt articulated this approach to emergencies when he opined that presidents may ignore statutory provisions when "necessary to avert a disaster which would interfere with the winning of the war." "71

Committing troops to combat offers one of the most high-profile examples of this relativist view on a national level. As James Madison once noted, "War is in fact the true nurse of executive aggrandizement." " Indeed, both wars and pandemics offer opportunities for ambitious executives to exploit our fears and our innate desire for order during emergencies. The U.S. Constitution assigns Congress the power to declare war. ${ }^{73}$ Accordingly, we the people, through our representatives, should decide whether our children fight and die in foreign wars. Although our presidents command the military, they do not decide when to send troops into combat - except when our country suffers invasion or civil insurrection. ${ }^{74}$ Yet for generations now the Presidency has eroded this Constitutional guarantee through a strong view of executive war powers. ${ }^{75}$ For instance, President Harry Truman led the country into war in Korea without first

65. Id. at 126 .

66. Lobel, supra note 58, at 1409.

67. See id. at 1420-21.

68. See Huq \& Michaels, supra note 59, at 354-56.

69. Nixon v. Adm'r of Gen. Servs., 433 U.S. 425, 443 (1977).

70. Mistretta v. United States, 488 U.S. 361, 386 (1989).

71. 88 CONG. REC. 7040,7044 (1942).

72. James Madison, Letters of Helvidius, No. $I V$, in 6 Writings of JAMES MADison 174 (Gaillard Hunt ed., 1906).

73. U.S. CONST. art. I, $\S 8$, cl. 11.

74. See Richard F. Grimmett, Cong. Research Serv., RL33532, War Powers Resolution: Presidential Compliance 2 (2012); see also U.S. Const. art. I, § 8, cl. 11-12 (granting Congress the power to declare war and raise and support the Armed Forces); id. art. II, $\S 2$, cl. 1 (designating the President as the Commander in Chief of the Armed Forces).

75. GRIMMETT, supra note 74, at 23-25. 
obtaining congressional authorization. ${ }^{76}$ Later, the United States waged undeclared war in Vietnam under Presidents Lyndon Johnson and Richard Nixon. ${ }^{77}$

Following the War Powers Resolution, which Congressional sponsors alleged would restrain the executive, presidents received free rein to send troops to war so long as they notify Congress first. $^{78}$ Members of Congress applauded themselves for demanding they could intervene within sixty days to halt presidentially initiated conflict, ${ }^{79}$ even though it was unlikely Congress would ever end support with American troops engaged in combat. Congress failed to assert its single most important Constitutional obligation and check on the presidency: deciding, as the peoples' representatives, if and when America wages war. ${ }^{80}$

Since the 1973 War Powers Act, our presidents have waged war in over 130 conflicts, every conflict initiated solely by the executive and only later reported to Congress. ${ }^{81}$ Presidents Ronald Reagan and George Bush Sr. used the War Powers Act. ${ }^{82}$ President Bill Clinton used it to engage in Yugoslavia, Bosnia, Kosovo, Iraq, and Haiti, among other places. ${ }^{83}$ President George W. Bush used that act to respond to terrorist attacks after September 11, 2001. ${ }^{84}$ President Barack Obama used it frequently as well, most notably in Libya ${ }^{85}$; and President Donald Trump joined this tradition of waging war without declaring war for airstrikes in Syria. ${ }^{86}$ Although the United States has not declared war since 5 June $1942,{ }^{87}$ no one can deny our country has waged war many, many times since then, mostly on the sole word of the president. ${ }^{88}$

76. President Truman asserted that no congressional authorization was necessary because there was no war on the Korean peninsula. Louis Fisher, The Korean War: On What Legal Basis Did Truman Act?, 89 AM. J. INT'L L. 21, 21 (1995).

77. J. Gregory Sidak, To Declare War, 41 Duke L.J. 27, 41 (1991).

78. 50 U.S.C. $\$ 1542(2020)$.

79. See id. § 1544(b); see also Thomas M. Franck \& Clifford A. Bob, The Return of HumptyDumpty: Foreign Relations Law After the Chadha Case, 79 Am. J. INT'L L. 912, 918 (1985).

80. Cf. War Powers Resolution, 50 U.S.C. $\S \S 1541-1548$ (2020).

81. See generally GRIMMETT, supra note 74.

82. Id. at 6,14 .

83. Id. at 3-10.

84. Id. at 25; see also Authorization for Use of Military Force, S.J. Res. 23, 107th Cong. (2001) (a joint resolution authorizing the President to "use all necessary and appropriate force against those nations, organizations, or persons he determines planned, authorized, committed, or aided the terrorist attacks that occurred on September 11, 2001").

85. GRIMMETT, supra note 74, at 12.

86. Charlie Savage, Trump Had Power to Attack Syria Without Congress, Justice Dept. Memo Says, N.Y. Times (June 1, 2018), https://www.nytimes.com/2018/06/01/us/politics/trumpwar-powers-syria-congress.html [https://perma.cc/V8Z5-BP48].

87. Barbara Salazar Torreon \& Sofia Plagakis, Cong. Research Serv., R42738, Instances of Use of United States Armed Forces AbroAd, 1798-2020, at 10 (2020).

88. See id. at 2-47. 
At both national and state levels, and in both emergencies and nonemergencies, American democracy increasingly works this way: the executive directs, the bureaucracy enacts, the judiciary imposes. The legislature directly representing the citizenry may do nothing at all. United States Supreme Court Associate Justice Antonin Scalia expressed the importance of separation of powers and such separation's ability to protect minorities, both in normal times and in emergencies:

[I]f you think that the Bill of Rights is what sets us apart, you are crazy. Every banana republic has a bill of rights. Every president for life has a bill of rights. The bill of rights of the former evil empire, the Union of Soviet Socialist Republics, was much better than ours. I mean that literally. It was much better. We guarantee freedom of speech and of the press. Big deal. They guaranteed freedom of speech, of the press, of street demonstrations and protests, and anyone who is caught trying to suppress criticism of the government will be called to account. Whoa, that is wonderful stuff.

Of course, they were just words on paper, what our Framers would have called "a parchment guarantee." . . . [T] he word "constitution;" it does not mean a bill of rights, it means structure[, . . which] is what our Framers debated that whole summer in Philadelphia, in 1787. [Our Framers] did not talk about a Bill of Rights; that was an afterthought, wasn't it? The real constitution of the Soviet Union did not prevent the centralization of power in one person or in one party. And when that happens, the game is over. The bill of rights becomes what our Framers would call "a parchment guarantee."

So the real key to the distinctiveness of America is the structure of our Government. One part of it, of course, is the independence of the judiciary, but there is a lot more. There are very few countries in the world, for example, that have a bicameral legislature. England has a House of Lords for the time being, but the House of Lords has no substantial power. It can just make the Commons pass a bill a second time. France has a senate; it is honorific. Italy has a senate; it is honorific. Very few countries have two separate bodies in the legislature equally powerful. It is a lot of trouble . . . to get the same language through two different bodies elected in a different fashion.

Very few countries in the world have a separately elected chief executive. Sometimes I go to Europe to speak in a seminar on separation of powers, and when I get there, I find that all we are talking about is independence of the judiciary. Because the Europeans do not even try to divide the two political powers, the two political branches - the legislature and the chief executive. In all of the parliamentary countries, the chief executive is the creature of the legislature. There is never any disagreement between the majority in the legislature and the prime minister, as there is sometimes between [Congress] and the President. When there is a disagreement, they just kick him out. They have a noconfidence vote, a new election, and they get a prime minister who agrees with the legislature. 
You know, the Europeans look at our system, and they say, well, the bill passes one House, it does not pass the other House (sometimes the other House is in the control of a different party). It passes both Houses, and then this President, who has a veto power, vetoes it. They look at this and they say, "It is gridlock."

And I hear Americans saying this nowadays, and there is a lot of it going around. They talk about a dysfunctional Government because there is disagreement. And the Framers would have said, "Yes, that is exactly the way we set it up. We wanted this to be power contradicting power because the main ill that besets us," as Hamilton said in the Federalist paper when he justified the inconvenience of a separate Senate, ["]is an excess of legislation." This is 1787 . They did not know what an excess of legislation was.

So unless Americans should appreciate that and learn to love the separation of powers, which means learning to love the gridlock that it sometimes produces. The Framers believed that would be the main protection of minorities - the main protection. If a bill is about to pass that really comes down hard on some minority, so that they think it terribly unfair, it does not take much to throw a monkey wrench into this complex system.

So Americans should appreciate that, and they should learn to love the gridlock. It is there for a reason: so that the legislation that gets out will be good legislation. ${ }^{89}$

Separating powers among branches of government helps define the character of our political system. As Chief Justice Warren Burger wrote during a dispute over President Nixon's tape recordings, separation of powers was "the characteristic that distinguished our system from all others conceived up to the time of our Constitution." ${ }^{90}$ By separating powers among branches, the Founders sought to safeguard against tyranny. ${ }^{91}$ James Madison explained in Federalist 51 that preserving liberty necessarily meant assuming ambition in those who sought power and creating a system to check that ambition:

[T] he great security against a gradual concentration of the several powers in the same department, consists in giving to those who administer each department, the necessary constitutional means, and personal motives, to resist encroachments of the others. . . Ambition must be made to counteract ambition. The interest of the man must be connected with the constitutional rights of the place. ${ }^{92}$

Madison and other Founders understood that emergencies threaten liberty and

89. Considering the Role of Judges Under the Constitution of the United States: Hearing Before the S. Comm. on the Judiciary, 112th Cong. 6-8 (2011) (statement of Hon. Antonin Scalia, Associate Justice, Supreme Court of the United States).

90. Nixon v. Adm'r of Gen. Servs., 433 U.S. 425, 507 (1977) (Burger, C.J., dissenting).

91. See generally The Federalist No. 51 (James Madison).

92. Id. 
open the door wide to lust for power. ${ }^{93}$ Such persons of ambition justify violence in the name of safety; they set aside due process and legal formalities for efficiency, diminish free speech and free association for pursuit of unity. Transparency becomes an annoyance. We need separation of powers and checks and balances not merely in spite of emergencies, but often because of them. A strict separation of powers is more, not less, important during crises.

\section{Hoosier Confrontations with Separation of Powers}

Like its national counterpart, the Indiana Constitution includes a complex set of checks and balances between and among branches. ${ }^{94}$ Article 3 of the Indiana Constitution sets forth the state's separation of powers doctrine: "The powers of the Government are divided into three separate departments; the Legislative, the Executive including the Administrative, and the Judicial; and no person, charged with official duties under one of these departments, shall exercise any of the functions of another, except as in this Constitution expressly provided."'95

Like our national government, Indiana disallows the executive branch's enacting laws on its own; this authority rests with the state's legislature. ${ }^{96}$ Even during emergencies, the state's constitution provides that only the legislature may compromise rights: "The operation of the laws shall never be suspended, except by the authority of the General Assembly." ${ }^{97}$

Although the three branches remain separate, both the United States and Indiana adopted a Madisonian system of checks and balances so that each branch exercises limited control over functions of the other branches. The Founders expected these checks and balances to prevent overreach by one branch and to discourage unsound proposals. ${ }^{98}$ The president and governor wield some legislative power through the veto, and the Senate retains a role in executing laws through its power to confirm or reject some nominees for high office. ${ }^{99}$ Unlike its national counterpart, the Indiana General Assembly may also override executive veto by simple-majority vote in each chamber. ${ }^{100}$

But, as in ancient Rome, emergencies afford Hoosier governors and mayors opportunity to set aside many checks and balances. Indiana's Oliver P. Morton, governor from 1861 to 1867, did not avoid executive action even when he lacked legislative approval. ${ }^{101} \mathrm{He}$ established a state arsenal, disbanded the legislature

93. Id.

94. See Ind. Const. arts. 3-7.

95. Id. art. $3, \S 1$.

96. Id. art. 4, $\S 1$ ("The Legislative authority of the State shall be vested in the General Assembly, which shall consist of a Senate and a House of Representatives. The style of every law shall be: 'Be it enacted by the General Assembly of the State of Indiana'; and no law shall be enacted, except by bill.”).

97. Id. art. $1, \S 26$.

98. The Federalist No. 51 (James Madison).

99. See U.S. Const. art. I, § 7; InD. Const. art. 5, § 14; U.S. Const. art. II, § 2, cl. 2.

100. InD. CONST. art. 5, § 14(2)(B).

101. See A. James Fuller, Oliver P. Morton and the Politics of the Civil War and 
over a state-militia dispute, and unconstitutionally secured millions of dollars in federal and private loans to avoid calling a special session of the state legislature in $1862 .{ }^{102}$

During the COVID 19 pandemic in 2020, Indiana joined other states in mandating travel restrictions, lockdowns, business closures, and face masks to slow the disease's spread. ${ }^{103}$ As it became a serious public health threat in the United States in March 2020, officials feared Indiana's ability to handle expected demand on medical providers, hospital beds, and ventilators. ${ }^{104}$ Visualizing a line graph's spike in cases, officials sought to "flatten the curve" to prevent patients from overwhelming the health system. ${ }^{105}$ Acting pursuant to the state's emergency powers law, Indiana's Governor Eric Holcomb declared a public emergency in Executive Order 20-02 and subsequently issued dozens of other executive orders seeking to limit the pandemic's spread. ${ }^{106}$ Among other things, his executive orders limited gathering sizes, required citizens to stay at home except for "essential" business, prohibited on-site dining and drinking at bars and restaurants, postponed or canceled non-emergency medical procedures, closed schools, delayed primary elections, and mandated use of face masks. ${ }^{107}$ Virtually every other governor issued similar or even stricter orders. ${ }^{108}$ Many public health experts regarded such steps as necessary to contain the pandemic's spread. ${ }^{109}$

But, even if such steps were necessary, the state should enact them in a constitutional manner limiting the potential abuse of power. In Indiana, gubernatorial responses to COVID-19 occurred over a period extending beyond nine months and never involved any legislative vote or formal legislative approval. ${ }^{110}$ For some of the most serious and consequential government actions

RECONSTRUCTION (2017).

102. Id. at 105-45.

103. See Justin L. Mack, Indiana Coronavirus Updates: Governor Orders Hoosiers to Stay at Home Starting Wednesday, Indianapolis StAR (Mar. 23, 2020), https://www.indystar. $\mathrm{com} /$ story/news/health/2020/03/23/indiana-coronavirus-updates-indianapolis-covid-19-latestnews/2896967001 [https://perma.cc/K9M5-2ADS].

104. Id.

105. See Siobhan Roberts, Flattening the Coronavirus Curve, N.Y. Times (Mar. 27, 2020), https://www.nytimes.com/article/flatten-curve-coronavirus.html [https://perma.cc/6974-BJCS].

106. See InD. Code $\S \S 10-14-3-1$ to -34 (2021); Ind. Exec. Order No. 20-02 (Mar. 6, 2020) https://www.in.gov/gov/governor-holcomb/newsroom/executive-orders [https://perma.cc/LG34R2YF].

107. See Ind. Exec. Order No. 20-04 (Mar. 16, 2020); Ind. Exec. Order No. 20-07 (Mar. 20, 2020); Ind. Exec. Order No. 20-08 (Mar. 23, 2020); Ind. Exec. Order No. 20-37 (July 24, 2020).

108. See generally State Government Responses to the Coronavirus (COVID-19) Pandemic, 2020, BALlOTPEDIA, https://ballotpedia.org/State_government_responses_to_the_coronavirus_ (COVID-19)_pandemic,_2020 (last visited Mar. 10, 2021) [https://perma.cc/CP6X-HLPK].

109. See Roberts, supra note 105. The authors of this Article take no position questioning the efficacy of these measures.

110. See generally 2020 Executive Orders, GOVERnOR HolcomB, https://www.in.gov/gov/ newsroom/executive-orders/2020-executive-orders/ (last visited Aug. 27, 2021) [https://perma. 
in generations, only one elected official made every decision during the pandemic in 2020 - without any formal checks or balances.

\section{THE MODERN APPROACH TO EMERGENCY LAWS}

\section{A. National Push for Emergency Laws}

In the early 1950s, the United States engaged in the Korean War-a devastating war between the Soviet-backed Democratic People's Republic of Korea in the north and the pro-Western Republic of Korea in the south. ${ }^{111}$ Even after the war ended in 1953, the United States and Soviet Union continued an escalating arms race that many Americans feared would lead to nuclear war. ${ }^{112}$ Consequently, the United States government and various state governments urged citizens to prepare for an atomic bomb. ${ }^{113}$

All states and most other jurisdictions of the United States enacted legislation in the 1950s modeled on the Interstate Civil Defense and Disaster Compact authorizing interstate agreements to establish a basic legal framework for mutual defense aid and disaster assistance. ${ }^{114}$ This framework, however, primarily addressed military preparedness and situations involving nuclear attack; most of the legislation failed to account for natural disasters and other emergencies. ${ }^{115}$ Eventually, policymakers called for a comprehensive emergency-response system designed for consistency and cooperation across various levels and types of interstate and intrastate government. ${ }^{116}$

Spurred largely by these growing concerns, in 1971, the Office of Emergency Preparedness (now FEMA - the Federal Emergency Management Agency) commissioned the Council of State Governments ("CSG") to create a "disaster project" to assist states with disaster planning. ${ }^{17}$ The CSG's Committee on Suggested State Legislation developed an "Example State Disaster Act" in 1972 as a model for states to use in updating disaster and emergency legislation. ${ }^{118}$ Notably, this model applied to a variety of national and state and local disasters, not just military ones, and authorized local governments of various states to enter into agreements with one another, thereby facilitating and encouraging disaster

cc/2YK2-8M92].

111. See Bruce Cumings, The Korean War: A History (2011).

112. See id. at 11 .

113. President Kennedy Urges Americans to Build Bomb Shelters, History, https://www. history.com/this-day-in-history/kennedy-urges-americans-to-build-bomb-shelters (last updated Oct. 5, 2020) [https://perma.cc/RRA4-22SY].

114. See Interstate Civil Defense and Disaster Compact, BALLOTPEDIA, https://ballotpedia.org/ Interstate_Civil_Defense_and_Disaster_Compact (last visited June 16, 2021) [https://perma.cc/ HPD7-RDDL]. Participating States adopted the Compact as written into their state codes.

115. Id.

116. Id.

117. See Office of Emergency Preparedness, Exec. Office of the President, Report to the Congress: Disaster Preparedness (1972).

118. Id. 
relief across state boundaries. After the CSG reported its model act to the Congressional Office of Emergency Preparedness, a number of states and territories adopted some form of the model. ${ }^{119}$

\section{B. Indiana's Emergency Management and Disaster Law}

In 1976, Indiana adopted the "Emergency Management and Disaster Law" ("EMDL"), then codified it at Indiana Code section 10-4-3. ${ }^{120}$ The EMDL defines disaster as "an occurrence or imminent threat of widespread or severe damage, injury, or loss of life or property resulting from any natural phenomenon or human act," including an "epidemic." "21 To address these emergencies, Indiana's legislature granted the governor broad authority. ${ }^{122}$ In addition to other powers, the governor may " $[\mathrm{u}] \mathrm{se}$ all available resources of the state government and of each political subdivision of the state reasonably necessary to cope with the disaster emergency." 123 In case the EMDL fails to provide sufficient flexibility and power, the governor may also "[m]ake, amend, and rescind the necessary orders, rules, and regulations to carry out [the EMDL] with due consideration of the plans of the federal government."124

The means to enforce these sweeping emergency powers are sweeping, too. Under the EMDL, the law enforcement authorities of the state and local governments (largely under the governor's authority and direction) possess the authority to enforce orders, rules, and regulations issued under the EMDL. ${ }^{125}$ Further, the governor may:

[t]ake any action and give any direction to state and local law enforcement officers and agencies as may be reasonable and necessary for securing compliance with this chapter and with any orders, rules, and regulations made under this chapter[,]

[and may e]mploy any measure and give any direction to the state department of health or local boards of health as is reasonably necessary for securing compliance with this chapter or with the findings or recommendations of the state department of health or local boards of health because of conditions arising from actual ... natural disasters or emergencies. ${ }^{126}$

Theoretically, these sweeping powers may last forever. With no assistance or

119. See, e.g., Disaster Preparedness and Assistance Legislation: Hearing on H.R. 7690 and Related Bills Before the Subcomm. on Water Resources of the H. Comm. on Public Works, 93d Cong. 227 (1973) (statement of Hon. A. R. Schwartz, Member, Tex. S. and National Legis. Conf. Comm. on Intergovernmental Relations).

120. Recodified at IND. CODE $\S 10-14-3$ in 2003.

121. IND. CoDE $\S 10-14-3-1$ (2020).

122. Id. § 10-14-3-12 (2003).

123. Id. $\S 10-14-3-12(\mathrm{~d})(2)(2020)$.

124. Id. § 10-14-3-11(b)(1).

125. Id. $\S 10-14-3-24$.

126. Id. § 10-14-3-11(b)(3)-(4). 
authorization from the legislature, the governor may declare an emergency by executive order or proclamation for a maximum of thirty days ${ }^{127}$; he may renew the disaster period for an unlimited number of times until the governor alone finds danger has passed or emergency conditions no longer exist. ${ }^{128}$ Although the legislature may end an emergency declaration any time, in practice they cannot do so when the legislature is not in session. ${ }^{129}$

\section{Local Emergency Powers}

Regarding local authority in Indiana, the EMDL grants municipal executives the power to declare an emergency for up to and including seven days. ${ }^{130}$ Local officials may renew such declarations an unlimited number of times "with the consent of the governing board of the political subdivision." 131 For an Indiana town and county, "governing board" undoubtedly means the town council and board of county commissioners, respectively; for a city, it means the city council. After declaring a local emergency, local officials may "waive procedures and formalities otherwise required by law pertaining to": performing public work, entering into contracts, incurring obligations, employing permanent and temporary workers, using volunteer workers, renting equipment, purchasing and distributing supplies and materials, and appropriating and spending public funds. ${ }^{132}$ In effect, these governing boards may ignore many norms and procedures following their emergency declaration.

The EMDL raises some guardrails for local authority such as preventing local declarations which prohibit employment necessary to "(1) maintain a safe rail system; (2) restore utility service; or (3) provide any other emergency public service." 133 Moreover, local governments "may not prohibit individuals trained and certified as first response [broadcasters] . . . from traveling on the highways." ${ }^{134}$ By implication, of course, local governments may restrict travel for all other individuals.

\section{Indiana's Public Health Emergencies}

In addition to emergency authority granted to the governor for emergencies (including pandemics), the General Assembly delegated broad authority to the Indiana State Department of Health ("ISDH") and local health departments to control communicable disease outbreaks - even in the absence of a public health

127. Id. § 10-14-3-12(a).

128. Id.

129. Id. (providing that the "general assembly, by concurrent resolution, may terminate a state of disaster emergency at any time").

130. Id. $\S 10-14-3-29(\mathrm{a})(2)$.

131. See id. Officials of an interjurisdictional emergency management agency may not declare an emergency. Id. § 10-14-3-29(c).

132. Id. § 10-14-3-17(j)(5); see also id. § 10-14-3-22.

133. Id. § 10-14-3-29(d).

134. Id. $\S 10-14-3-29(\mathrm{e})$. 
emergency. To this end, the ISDH may "do what is reasonable and necessary for the prevention and suppression of disease." 135

Likewise, Indiana historically granted vast powers to local health officers-unelected officials overseen by an unelected board of health-who could adopt and enforce virtually any rule necessary to prevent or stop epidemics. ${ }^{136}$ They may close schools and churches and forbid public gatherings. ${ }^{137}$ Both state and local health officers may issue orders for isolation and quarantine, ${ }^{138}$ emergency orders for isolation and quarantine, ${ }^{139}$ and immediate orders for isolation and quarantine. ${ }^{140}$

In 2015, when an HIV outbreak occurred in Scott County, Indiana, following mass exposures among injecting drug users, Governor Mike Pence issued an executive order subsequently declaring a public health emergency; then, the State Health Commissioner declared and extended the public health emergency in Scott County. ${ }^{141}$ Together, these declarations allowed the Scott County Health Department to administer a needle exchange program to combat HIV. ${ }^{142}$

The General Assembly took some steps to reign in local health department power. In 2021, the Indiana legislature enacted Public Law 219, over Governor Holcomb's veto, providing that "[i]f a local order addresses an aspect of a declared emergency addressed by a[ state] executive order, the local order may be less stringent than the executive order to the extent permitted by the executive order," 143 but it may not be more stringent. A local health order also could not go into effect if no state executive order on the matter existed. ${ }^{144}$

Several provisions in the state infectious disease control law allow for criminal prosecution of violations of public health rules. ${ }^{145}$ Furthermore, violation of some public health-related orders, such as quarantine, may result in prosecution as a Class A misdemeanor. ${ }^{146}$

\section{SUGGESTED REFORMS TO INDIANA EMERGENCY POWERS}

\section{A. Comparative Policy Review}

The COVID-19 pandemic highlights the executive's seemingly unchecked

135. Id. § 16-19-3-9.

136. Id. $\S \S 16-20-2-6,-16$.

137. Id. $\S 16-19-13-10$.

138. Id. § 16-41-9-1.5(a)-(d).

139. Id. § 16-41-9-1.5(e)-(j).

140. Id. § 16-41-9-1.5(k).

141. Ind. Exec. Order No. 15-05 (Mar. 26, 2015).

142. Id. Syringe exchange programs were illegal except in a declared public health emergency. Id.; IND. CODE $\S \S 16-42-19-18,35-48-4-8.5(\mathrm{a})(1), 35-48-8.3-(\mathrm{b})(1)$.

143. Act of May 10, 2021, Pub. L. No. 219-2021, 122d Gen Assemb., 1st Reg. Sess. (Ind. 2021) (enacted); IND. CODE $§ 16-20-1-21.5(\mathrm{e})$ (2021).

144. IND. CODE $\S 16-20-1-19$.

145. See, e.g., IND. CoDE $\S 16-41-6-3$ (1993).

146. IND. CODE $\S 16-41-9-1.5(\mathrm{t})(2006)$. 
power during crises. Often these unchecked powers lacking legislative assistance and authority result in head-scratching policy. For example, Michigan Governor Gretchen Whitmer banned the sale of "nonessential" items such as furniture, carpeting, and paint even in stores allowed to remain open, ${ }^{147}$ action suggesting that buying a can of paint at Target during the pandemic somehow posed greater health risks than buying a can of soda from that store. In Illinois, Governor J. B. Pritzker's executive orders allowed visits to stores like Target and Walmart for furniture, clothing, and groceries, but banned visits to furniture stores, clothing stores, and florists - even though those stores could adopt the same safety measures required of other retail businesses. ${ }^{148}$

Only two states, Georgia and Oklahoma, require affirmative legislative action to approve a governor's initial declaration of emergency. ${ }^{149}$ Seven other states require legislative approval of extensions once an initial emergency declaration expires. ${ }^{150}$ Twenty-two state legislatures possess neither of these powers, though they may nullify their governors' emergency declarations. ${ }^{151}$ In the remaining nineteen states, a governor's emergency declaration closing private business, restricting commerce, or limiting free movement has no limits at all. ${ }^{152}$

In response to this dizzying and arbitrary executive power, state legislatures across the United States introduced proposals - with varying degrees of success - to reaffirm the legislature's role during emergencies. In Alabama, a proposal failed which would have ended states of emergency after fourteen days unless extended by joint resolution of the bicameral legislature. ${ }^{153}$ State legislatures also proposed - and failed to pass - attempts to bolster legislative authority in California, ${ }^{154}$ Delaware, ${ }^{155}$ Minnesota, ${ }^{156}$ Missouri, ${ }^{157}$ North

147. Mich. Exec. Order No. 2020-42 (2020).

148. See Ill. Exec. Order No. 2020-32 (2020).

149. Ga. Code Ann. § 38-3-51 (1951); Okla. Stat. tit. 63, § 6405 (2003); see also Legislative Oversight of Emergency Powers, NAT'L Conf. St. Legislatures (Feb. 23, 2021), https://www.ncsl.org/research/about-state-legislatures/legislative-oversight-of-executiveorders.aspx [https://perma.cc/299Q-XYJX].

150. See Legislative Oversight of Emergency Powers, supra note 149.

151. Id.

152. Id.

153. S.B. 334, 2020 Leg., Reg. Sess. (Ala. 2020).

154. A.B. 1857, 2020 Leg., Reg. Sess. (Cal. 2020); S. Con. Res. 93, 2020 Leg., Reg Sess. (Cal. 2020).

155. H.B. 330, 150th Leg., Reg. Sess. (Del. 2020).

156. H.B. 4572, 91 st Leg., Reg. Sess. (Minn. 2020); H.B. 4592, 91 st Leg., Reg. Sess. (Minn. 2020); H.B. 4629, 91 st Leg., Reg. Sess. (Minn. 2020); H.B. 4648, 91st Leg., Reg. Sess. (Minn. 2020); H.B. 4657, 91st Leg., Reg. Sess. (Minn. 2020); H.B. 22, 91 st Leg., 4th Spec. Sess. (Minn. 2020); H.B. 81, 91 st Leg., 1 st Spec. Sess. (Minn. 2020); H.B. 139, 91 st Leg., 1st Spec. Sess. (Minn. 2020); S.B. 4519, 91st Leg., Reg. Sess. (Minn. 2020); S.B. 4583, 91st Leg., Reg. Sess. (Minn. 2020); S.B. 55, 91 st Leg., 1st Spec. Sess. (Minn. 2020).

157. H. Res. 5502, 100th Leg., 2d Reg. Sess. (Mo. 2020). 
Carolina, ${ }^{158}$ Tennessee, ${ }^{159}$ Virginia,${ }^{160}$ and Wisconsin. ${ }^{161}$

But other legislatures achieved some success. For instance, the Colorado legislature enacted requirements for the executive branch to deliver certain information during a declared disaster emergency; other oversight measures, however, failed. ${ }^{162}$ Hawaii enacted new requirements for all executive branch departments and attached agencies to inform the Senate and House of Representatives when implementing their plans and procedures relating to the coronavirus pandemic. ${ }^{163}$ The Kansas legislature adopted provisions giving the Legislative Coordinating Council authority to review and revoke all orders and proclamations the governor issues. ${ }^{164}$ In addition, Kansas enacted legislation amending the Kansas Emergency Management Act and prohibiting the governor from proclaiming any new COVID-19 related emergency in 2020 without approval of at least six legislative members of the State Finance Committee. ${ }^{165}$ Michigan adopted resolutions allowing the Speaker of the House and the Senate Majority Leader to commence legal action on behalf of each legislative body challenging the governor's authority and actions during the coronavirus pandemic, ${ }^{166}$ but a separate bill failed to reduce the length of orders, proclamations, and directives issued by the governor under Michigan's Emergency Management Act. ${ }^{167}$ The Pennsylvania legislature adopted amendments to the Constitution of the Commonwealth relating to emergency declarations and general assembly approval. ${ }^{168} \mathrm{~A}$ new Utah law requires the governor to notify certain legislative branch officers before declaring a state of emergency or issuing other executive orders or actions in response to an epidemic or pandemic disease. ${ }^{169}$

158. H.B. 1170, 2020 Gen. Assemb., Reg. Sess. (N.C. 2020); S.B. 781, 2020 Gen. Assemb., Reg. Sess. (N.C. 2020).

159. H.B. 2931, 111 th Leg., Reg. Sess. (Tenn. 2020); S.B. 2938, 111 th Leg., Reg. Sess. (Tenn. 2020).

160. H.J. Res. 5001, 2020 Gen. Assemb., 1st Spec. Sess. (Va. 2020); H.J. Res. 5003, 2020 Gen. Assemb., 1st Spec. Sess. (Va. 2020); H.J. Res. 5005, 2020 Gen. Assemb., 1st Spec. Sess. (Va. 2020); S.B. 5001, 2020 Gen. Assemb., 1st Spec. Sess. (Va. 2020); S.B. 5008, 2020 Gen. Assemb., 1st Spec. Sess. (Va. 2020); S.B. 5111, 2020 Gen. Assemb., 1st Spec. Sess. (Va. 2020).

161. A.B. 1037, 104th Leg., Reg. Sess. (Wis. 2020); A.B. 923, 104th Leg., Reg. Sess. (Wis. 2020).

162. H.B. 1426, 72d Gen. Assemb., Reg. Sess. (Colo. 2020) (enacted); H.R. Con. Res. 1002, 72d Gen. Assemb., Reg. Sess. (Colo. 2020); S. Con. Res. 2, 72d Gen. Assemb., Reg. Sess. (Colo. 2020).

163. S. Res. 166, 30th Leg., Reg. Sess. (Haw. 2020) (enacted).

164. H.R. Con. Res. 5025, 2020 Leg., Reg. Sess. (Kan. 2020) (enacted).

165. H.B. 2016, 2020 Leg., Reg. Sess. (Kan. 2020) (enacted).

166. H. Res. 250, 100th Leg., Reg. Sess. (Mich. 2020); S. Res. 250, 100th Leg., Reg. Sess. (Mich. 2020).

167. S.B. 858, 100th Leg., Reg. Sess. (Mich. 2020).

168. S.B. 1166, 2020 Gen. Assemb., Reg. Sess. (Pa. 2020).

169. H.B. 3005, 2020 Leg., 3d Spec. Sess. (Utah 2020). 
Some proposals remained unresolved as of the time of this writing. In Illinois, for example, pending legislation stipulates the governor may extend a disaster declaration or issue further proclamations regarding the same disaster only "if the General Assembly passes a resolution within 5 calendar days that approves the extension or further proclamation"; but if health or safety concerns persist, an extension may continue until the General Assembly is able to convene in regular or special session. ${ }^{170} \mathrm{~A}$ bill in the Kentucky General Assembly seeks to limit the effective dates of executive orders issued by the governor unless the legislature approves an extension. ${ }^{171}$ Moreover, this bill seeks to "prohibit the Governor from issuing a new executive order relating to the same emergency" without the General Assembly's approval. ${ }^{172}$ A slew of other proposals in Louisiana, ${ }^{173}$ Montana, ${ }^{174}$ New Jersey, ${ }^{175}$ Nevada, ${ }^{176}$ New York,,${ }^{177}$ Ohio, ${ }^{178}$ South Carolina, ${ }^{179}$ and Texas ${ }^{180}$ sought to limit gubernatorial powers during a declared emergency with varying levels of success.

170. H.B. 5776, 101st Gen. Assemb., Reg. Sess. (Ill. 2020); S.B. 3987, 101st Gen. Assemb., Reg. Sess. (Ill. 2020).

171. S.B. 1, 2021 Gen Assemb., Reg. Sess., (Ky. 2021) (seeking to amend KRS 39A.090).

172. Senate Bill 1, Ky. Gen. Assembly, https://apps.legislature.ky.gov/record/21rs/sb1.html (last visited Aug. 12, 2021) [https://perma.cc/P9U8-JEXL].

173. H.B. 17, 2020 Leg., 2d Spec. Sess. (La. 2020) (providing for the termination of emergency declarations); H.B. 11, 2020 Leg., 2d Spec. Sess. (La. 2020) (limiting the duration of certain, specified public health emergencies unless an extension is authorized by the Legislature). See also H.B. 57, 2020 Leg., 2d Spec. Sess. (La. 2020); H.B. 61, 2020 Leg., 2d Spec. Sess. (La. 2020); H.B. 68, 2020 Leg., 2d Spec. Sess. (La. 2020); H.R. Con. Res. 9, 2020 Leg., 2d Spec. Sess. (La. 2020); H.R. Con. Res. 16, 2020 Leg., 2d Spec. Sess. (La. 2020); S.B. 29, 2020 Leg., 2d Spec. Sess. (La. 2020); S.B. 35, 2020 Leg., 2d Spec. Sess. (La. 2020); S.B. 39, 2020 Leg., 2d Spec. Sess. (La. 2020); S.B. 43, 2020 Leg., 2d Spec. Sess. (La. 2020); S.B. 48, 2020 Leg., 2d Spec. Sess. (La. 2020); S. Con. Res. 8, 2020 Leg., 2d Spec. Sess. (La. 2020).

174. Mont. Bill Draft No. LC0653 (2020).

175. A.B. 1417, 219th Leg., Reg. Sess. (N.J. 2020); A.B. 4212, 219th Leg., Reg. Sess. (N.J. 2020); A.B. 4255, 219th Leg., Reg. Sess. (N.J. 2020); Assemb. Con. Res. 181, 219th Leg., Reg. Sess. (N.J. 2020); S.B. 2482, 219th Leg., Reg. Sess. (N.J. 2020); S.B. 2613, 219th Leg., Reg. Sess. (N.J. 2020); S. Con. Res. 117, 219th Leg., Reg. Sess. (N.J. 2020).

176. B.D.R. 41 (Nev. 2021); B.D.R. 178 (Nev. 2021) (withdrawn).

177. A.B. 6384, 2020 Assemb., Reg. Sess. (N.Y. 2020); A.B. 10449, 2020 Assemb., Reg. Sess. (N.Y. 2020); A.B. 10546, 2020 Assemb., Reg. Sess. (N.Y. 2020); A.B. 10918, 2020 Assemb., Reg. Sess. (N.Y. 2020); S.B. 8466, 2020 Assemb., Reg. Sess. (N.Y. 2020); S.B. 8924, 2020 Assemb., Reg. Sess. (N.Y. 2020).

178. H.B. 617, 133d Gen Assemb., Reg. Sess. (Ohio 2020); H.B. 618, 133d Gen Assemb., Reg. Sess. (Ohio 2020); H.B. 682, 133d Gen Assemb., Reg. Sess. (Ohio 2020); S.B. 311, 133d Gen Assemb., Reg. Sess. (Ohio 2020).

179. H.B. 5473, 2020 Leg., 123d Sess. (S.C. 2020); H.B. 5488, 2020 Leg., 123d Sess. (S.C. 2020); S.B. 1200, 2020 Leg., 123d Sess. (S.C. 2020); S.B. 1203, 2020 Leg., 123d Sess. (S.C. 2020).

180. H.B. 340, 87th Leg., Reg. Sess. (Tex. 2021); H.R.J. Res. 15, 87th Leg., Reg. Sess. (Tex. 2021). 


\section{B. Recommendations for Hoosier Reform}

The Indiana EMDL sets aside most checks and balances built into the separation of powers doctrine in favor of efficient, expedient powers for the governor. Although some emergency situations surely require swift authority, many emergency responses - certainly the restrictions and precautions resulting from COVID-19 - could have and should have incorporated legislative authority, assistance, and approval from the Indiana General Assembly. The legislature never granted the governor authority to issue decrees making a violation of his executive orders a criminal act. Alternatively, if it did intend to grant the governor power to create new criminal violations, it either gave away more power than allowed under the separation of powers doctrine, or the EMDL should include more specific guidance to executive agencies to help agencies avoid overreach.

If the Indiana General Assembly wished to place additional limits on the governor's actions during an emergency, it could do so by amending the EMDL - as the legislature has done before: for example, in 2010, it prohibited emergency actions from restricting lawful firearms possession, sale, and use. ${ }^{181}$ Governor Holcomb acknowledged those restraints during the COVID-19 pandemic by protecting gun and ammunition sales in his early executive orders. ${ }^{182}$ Likewise, Indiana's emergency management law includes an express exception for news media: nothing in general emergency provisions may "[i]nterfere with the dissemination of news or comment on public affairs." ${ }^{183}$ Nevertheless, the law continues, "a communications facility or organization, including radio and television stations, wire services, and newspapers, may be required to transmit or print public service messages furnishing information or instructions in connection with a disaster emergency." 184

Here, we focus on three opportunities for reform. First, all emergency declarations should carry a built-in, statutory, sunset provision requiring legislative approval for renewal or extension. Second, the legislature should require that even temporary emergency declarations win approval from designated leaders of both the House of Representatives and the Senate. Finally, the Indiana General Assembly should possess authority to call a special session to address any emergency legislative needs or gubernatorial overreach.

1. Sunsetting Emergency Declarations.- Sunset clauses assert that a specific piece of legislation expires automatically on a specific date or requires legislative authorization for renewal. ${ }^{185}$ Black's Law Dictionary defines the tool as a "statute under which a governmental agency or program automatically terminates at the

181. IND. CODE $§ 10-14-3-33.5$ (2020).

182. Ind. Exec. Order No. 20-08 (Mar. 23, 2020).

183. IND. CODE $\S 10-14-3-8(a)(2)$.

184. Id.

185. For a thorough analysis of sunset clauses, including an incomplete historical overview, see Sofia Ranchordás, Constitutional Sunsets and Experimental Legislation: A Comparative Perspective (2014). 
end of a fixed period unless it is formally renewed." ${ }^{186}$ Sunset clauses grew in popularity throughout the twentieth century to combat legislative inertia and eliminate unnecessary laws, programs, and agencies. ${ }^{187}$ Depending on their particulars, sunsetting emergency powers may limit an executive's extraordinary powers and bolster legislative oversight. Thus, any executive's emergency powers would require new legislative decisions and, in the process, require more frequent interaction between executive and legislative branches, allowing the benefits of separate branches to bear fruit. Furthermore, sunset provisions grant legislatures time to study a matter before making an action permanent. By no means do sunset clauses provide a cure-all; sadly, legislatures may still renew emergency orders without necessary review. But sunset clauses nevertheless provide metaphorical speed bumps for any executive seeking to abuse power.

Indiana should adopt sunset provisions for any emergency order the governor issues, including those pursuant to the EMDL. After the governor issues an emergency order, any renewal or extension of that order or issuance of one substantially like it beyond thirty days should require explicit approval by the legislature. Thus, the governor may respond quickly to an emergency, but then must submit the emergency action to periodic examination and approval by legislators.

2. Expanding Legislative Assistance.-Legislatures must renew American government's greatest strength - a diverse separation of powers. Improved decision-making results when disparate branches of government offer varied views. Moreover, this separation ensures adequate voter participation and demonstrates the approval that enhances defensibility and support necessary to enforce any order. To achieve this, the Indiana General Assembly should require that the Speaker of the House and Senate Majority Leader approve in writing any temporary executive order.

3. Enabling Special Session Authority.-Special sessions, as opposed to regular sessions, may address a specific state issue such as a public-health emergency. But Indiana's Constitution vests the power to call a special session exclusively with the governor ${ }^{188}$ :

The sessions of the General Assembly shall be held at the capital of the

186. Sunset Clause, Black's LaW Dictionary (8th ed. 2004).

187. See Mark B. Blickle, The National Sunset Movement, 9 Seton Hall Legis. J. 209, 210 12 (1985). For a more recent analysis of sunset clauses, see Symposium, Showcase Panel IV: A Federal Sunset Law, 16 Tex. Rev. L. \& Pol. 339, 342 (2012).

188. See IND. CODE $\S 2-2.1-1-4$ (providing that "[a] special session of the [G]eneral [A]ssembly, called by the [G]overnor as provided in article 4, section 9 of the Constitution of the [S] tate of Indiana, shall continue for not more than thirty (30) session days nor more than forty (40) calendar days following the day upon which it is commenced"); Casey Smith, Indiana Democrats Call for Special Legislative Session, Associated Press (July 21, 2020), https://apnews.com/article/849385fc35ca5e462fla597adeb16d33 [https://perma.cc/NZL5-CNG2] (Indiana legislators urged Governor Holcomb to call a special session to address police reform measures and COVID-19 relief, but Governor Holcomb said "a special session wasn't 'on [his] agenda right now."”). 
State, commencing on the Tuesday next after the second Monday in January of each year in which the General Assembly meets unless a different day or place shall have been appointed by law. But if, in the opinion of the Governor, the public welfare shall require it, he may, at any time by proclamation, call a special session. The length and frequency of the sessions of the General Assembly shall be fixed by law. ${ }^{189}$

In the First Regular Session of the 122nd General Assembly (held in 2021), "House Enrolled Act 1123 . . . authorize[d] the [Indiana legislature] to convene an emergency session ... when the Governor declares a state of emergency under the [EMDL] and the [legislature] finds that it is necessary to address the state of emergency with legislative action." 190 HEA 1123 was adopted over the Governor's veto, and Governor Holcomb subsequently filed a lawsuit questioning the legality of the law based upon the Indiana constitutional provisions quoted above that suggest the Governor alone may call the legislature into a special session. ${ }^{191}$ As of this writing, Indiana courts have yet to rule on the substance of the dispute, but whether through constitutionally permissible legislation or a constitutional amendment, the Indiana legislature should seek to retain the power to call itself into session. Because the Indiana Constitution outlines the state's requirements for special sessions, expanding the legislature's authority to call such sessions may require an amendment to the Constitution.

In thirty-six states, either the governor or the legislature may call a special session. ${ }^{192}$ Many state legislatures therefore - depending upon the particularities stipulated in their respective session procedures - may call a special session to address a public-health emergency such as COVID-19 without the governor's authorization. To provide a check on potential executive branch abuses, particularly during emergencies, the legislature must possess authority to meet on its own volition at times of its choosing.

The legislature should pass laws at special sessions only if germane to, or clearly connected with, subjects stated in the call for a special session. Such a limitation ensures the public and interested parties may present their views on whatever matters the legislature then considers. Without such topical restrictions, the legislature might sneak in unrelated legislation without sufficient public notice. Second, this restriction ensures the special session's docket will not become clogged with business unrelated to the extraordinary events prompting the special session. Any questions or ambiguity about the legislature's proper scope of business should be construed in favor of legislative power, and anyone

189. IND. CONST. art. $4, \S 9$.

190. Verified Petition for Writ of Mandamus and Prohibition at 9 , State of Ind. ex rel. Ind. Gen. Assembly v. Marion Superior Court 12 (Dietrick), No. 21S-OR-00354 (Ind. Aug. 27, 2021) (citing IND. Code § 2-2.1-1.2); see also Act of Apr. 15, 2021, Pub. L. No. 64-2021, 122d Gen Assemb., 1st Reg. Sess. (Ind. 2021) (enacted).

191. See Marion Superior Court 12 (Dietrick), No. 21S-OR-00354.

192. Special Sessions, NAT'L CONF. St. Legislatures (Apr. 7, 2021), https://www.ncsl.org/ research/about-state-legislatures/special-sessions472.aspx [https://perma.cc/SBU5-VGXT]. 
attacking the validity of a legislature's actions during a special session should bear the burden of proof to show its defect.

\section{CONCLUSION}

The American Founders provided an insightful, healthy skepticism toward concentrations of power based on history's demonstrations of dangers without checks and balances. Sadly, our separation of powers - and the checks and balances brought with it - remains under constant stress. Emergencies pose the biggest threat to proper delineation of authority between executive and legislative branches. Although executives need flexibility to respond to emergencies, unfettered authority leads to disastrous consequences. Indiana must renew its commitment to separation of powers principles. Just as the Founding Fathers rejected hereditary monarchy, present-day Hoosiers must reject rule by executive fiat.

To restore appropriate checks and balances, Indiana's emergency laws should incorporate sunset provisions, include assistance and authority from the House of Representatives and Senate, and allow the General Assembly to call special sessions on its own. A streamlined and flexible emergency response system will coexist best with greater legislative participation and approval. 